Article

\title{
Who Benefits from Consociationalism? Religious Disparities in Lebanon's Political System
}

\author{
Kenneth Vaughan ${ }^{(1)}$ \\ Department of Sociology, Baylor University, Waco, TX 97326, USA; kenneth_vaughan@baylor.edu \\ Received: 28 November 2017; Accepted: 3 February 2018; Published: 8 February 2018
}

\begin{abstract}
This study examines the extent to which confessional identities in Lebanon are responsible for shaping individual views toward their government. Specifically, I investigate disparities between religious groups in their perceptions of democracy and democratic principles as applied in Lebanon. Using nationally representative data from the Arab Barometer's survey of Lebanon, I find that when compared to Maronite Catholics, Druze, and Sunni Muslims, Shia Muslims consistently give higher evaluations of the democratic condition of Lebanon. When compared to members of other religious groups, Shia Muslims are also more trusting of government institutions and perceive Lebanon to be freer. I find little evidence that the application of consociational theory equally and proportionally represents the political needs of the religious groups intended to be served. Rather, my findings reveal religious disparities in evaluations of democracy and political institutions in Lebanon, supporting critics of consociationalism who argue that consociationalism essentializes group-identity to political disputes.
\end{abstract}

Keywords: religion; ethnicity; Lebanon; Middle East; politics; consociationalism

Lebanon's consociational confessionalist government structure exists as an attempt to end interreligious conflict and to maintain religious equality. Specifically, this structure ensures that Christians and Muslims will occupy seats in the nation's parliament relative to their demographic presence and requires the President of Lebanon to be a Maronite Catholic, the Speaker of the Parliament a Shia Muslim, and their Prime Minister a Sunni Muslim (El-Husseini 2012; Salamey 2013). Other ministerial posts and political offices are also allocated according to religious confession in an attempt to maintain peace and equality. Eighteen official religious confessions are recognized, all of them Christian and Muslim, in addition to Judaism. These religious and political restrictions contribute to Lebanon being ranked as a moderate government regulator of religion. Additionally, social regulations of religious activity in Lebanon are high, which is often linked to further increased government restrictions on religious activity (Grim and Finke 2010; Pew Forum on Religion and Public Life 2014).

Consociationalists argue that distributing power based on ethnicity or religious identity can ease intergroup hostilities and strengthen a democracy. Indeed, since the implementation of Lebanon's most recent consociational arrangements, interreligious violence has significantly decreased. However, investigations into the effectiveness of these policies in establishing religious equality are warranted. Religious restrictions, including those mandating religion's influence in politics, are associated with decreased equality and increased conflict (Grim 2008; Grim and Finke 2007, 2010). Critics have also argued that consociationalism unnecessarily essentializes ethnic and religious identities to political disputes, which leads to intergroup inequality and conflict (Dixon 2011; Farha 2012; Haddad 2002; Hamzeh 2001).

In this study, I investigate the effectiveness of consociationalism in equally addressing the political needs of Lebanon's major religious groups and securing democracy in the eyes of Lebanese citizens. Using the Arab Barometer's survey of Lebanon, I investigated two important research questions. First, I ask whether or not Lebanon's major religious confessions believe that they equally benefit 
from their government's consociational democratic arrangements. Second, I ask how the benefits of consociational governance may be unequally distributed across religious confessions. In this study I find evidence that Lebanon's consociational form of government is not working equally for the religious groups it was intended to fairly represent. Shia Muslims consistently give the Lebanese government more positive evaluations on issues related to democracy when compared to Sunni Muslims, Maronite Catholics, and Druze. Maronite Catholics and Druze respondents consistently give the Lebanese government the most negative evaluations on these issues.

This study answers a call for further research identifying groups most impacted by religious restrictions, by investigating how institutions function under religious restrictions, and by investigating how religious restrictions impact avenues for political activities (Finke 2013). Among its most significant contributions, this research (1) directly addresses the sociology of religion by building a profile of religious attitudes in Lebanon; (2) brings an international focus to the sociological understanding of religion and state relations (Finke and Stark 2005; Gill 1998, 2008; Stark and Roger 2000); (3) bridges together parallel literatures on consociationalism in the fields of sociology and political science; and (4) bridges the sociology of religion and the sociology of race and ethnic relations by investigating a unique context where the politics of religion and the politics of race and ethnicity overlap.

\section{Review of Literature}

\subsection{Historical Context}

Consociational principles governed Lebanon for most of the 20th century and after. The National Pact of 1943, an unwritten agreement establishing Lebanon as a multi-confessional state, sets confessional requirements for Lebanon's most important political offices. The agreement also required that the parliament to be divided 6:5 with Christians holding more seats than Muslims. During this period, Christians benefited from their demographic majority status, majority presence in the parliament, and power afforded to the office of the President (Haddad 2002; Lijphart 1977; Salamey 2013).

Conflicts in 1958 and 1975 arose out of significant levels of discontent and anxiety regarding the future direction of the nation, with complaints being divided among confessional lines. Sunni and Shia Muslims were unhappy with Lebanon's power structure, which was seen as favoring Christians (Haddad 2002). Sunni Muslims were interested in drawing Lebanon closer to the rest of the Arab world, while Christians and Druze felt that this policy would lead to their being further marginalized as minorities in the region (Haddad 2002; MacKey 1991). Lebanese Druze were struggling to hold on to ethnic unity and land for living (Harik 1996; Kreidie and Monroe 2002). Confesionally motivated urbanization projects, which were designed to aid the nation's power-sharing goals, achieved a state of deadlock. With policies resulting in mass displacement, confessionally driven political deadlock, and sectarian identity overtaking national identity, sectarian tensions were exacerbated to the point of civil war (Farha 2012; Salamey and Tabar 2008). While the 1975 Civil War emerged with variegated interests in competition, belligerent participants were still significantly divided among confessional lines. The more secular, left-leaning, nationalist Lebanese National Movement had a significant Sunni and Druze presence. The predominantly Christian, right of center, Kataeb Party was more supportive of the confessional status-quo and economically was liberal. Hezbollah emerged as a major military representative of Shia Muslims and framed itself as a religious resistance organization (Baylouny 2014; Worrall et al. 2015).

Several political developments in post-war Lebanon have been largely beneficial to Sunni and Shia political interests, while Christians have lost a measurable amount of political influence, and the Druze have struggled with a sense of vulnerability (El-Husseini 2012; Haddad 2002; Harris 2012). Lebanon's Maronite population has "lost their grip on Lebanon" and "by the 1990s, there was a recognizable Christian collective with a common sense of frustration and disempowerment" (Harris 2012, p. 233). In accordance with the Taif Agreement, which was responsible for ending the Civil War, a significant amount of political power was transferred from the office of the President (a Maronite Catholic) to 
the office of the Prime Minister (a Sunni Muslim). The Shia led parliament was then delegated official control over most government activities (El-Husseini 2012). Christians lost their statistical majority status, and accordingly, their majority status in the parliament was replaced with a one-to-one split with Muslim parliamentarians (see Table 1). Christians have argued that official interpretations of the Taif Agreement are biased against them (Haddad 2002). Druze were left with an increasing sense of vulnerability to larger confessional groups. In the post-war era, the Druze have also struggled in not having their political leaders make the alignments they prefer (Harris 2012).

Table 1. Confessional Requirements for Major Political Offices According to the National Pact and Taif Agreement.

\begin{tabular}{cccccc}
\hline Agreement & President & $\begin{array}{c}\text { Prime } \\
\text { Minister }\end{array}$ & $\begin{array}{c}\text { Speaker of } \\
\text { Parliament }\end{array}$ & $\begin{array}{c}\text { Deputy Speaker of } \\
\text { the Parliament }\end{array}$ & $\begin{array}{c}\text { Proportion of } \\
\text { Parliament Members }\end{array}$ \\
\hline National Pact & Maronite Catholic & Sunni Muslim & Shia Muslim & Greek Orthodox & 6:5 Christian:Muslim \\
\hline Taif Agreement & Maronite Catholic & Sunni Muslim & Shia Muslim & Greek Orthodox & 1:1 Christian:Muslim \\
\hline
\end{tabular}

Source: El-Husseini (2012); Salamey (2013).

On the other hand, Sunnis "discovered the virtue of a multi-communal Lebanese state" and "became committed Lebanese as never before" (Harris 2012, p. 233).

Following the Civil War, Shias in Lebanon enjoyed a significant increase in representation in political structures and increased power through activities external to politics. While all militias were required to disarm at the end of the Civil War, Hezbollah, which currently courts the majority of Lebanon's Shia voters, was granted an exception (El-Husseini 2012). Hezbollah and the Amal movement, another Shia political party, have since made significant gains in the political sphere (Hamzeh 1994; Harik 1996; Harris 2012). While both parties made gains in Lebanon's first post-war election, frustrated Christians boycotted it (Harik 1996).

Hezbollah is now better armed than the Lebanese army, a fact that provokes a significant amount of criticism from members of Lebanon's other religious confessions. Hezbollah and the Syrian government have been accusing of assassinating Prime Minister Hariri, who represented the majority of Sunni citizens and had campaigned across sectarian lines with relative success. Hezbollah actively tried to block investigations into the assassination of Hariri, providing a sense of injustice among his supporters and exacerbating Sunni-Shia tensions (Bahout 2016; Cammett and Issar 2010; El-Husseini 2012; Harris 2012).

\subsection{Consociationalism}

Consociational theory is among the most prominent theories utilized for democratically managing societies that are religiously, ethnically, or otherwise segmented (Dixon 2011). Lijphart, while encouraging nations to adopt consociationalism, argued "if [political leaders of plural societies] wish to establish or strengthen democratic institutions in their countries, they must become consociational engineers" (Lijphart 1977, p. 223). This theory was initially developed to address divisions along ethnic, class, and religious lines in the Netherlands, Belgium, Austria, and Switzerland. Consociationalists have argued that consociationalism was responsible for the peace and political stability in these diverse nations, when many expected their diversity to cause the opposite (Lijphart 1977; McGarry and O'Leary 2006a; Wilkinson 2000). Lijphart has identified four principles which he believes dampens ethnic and religious conflict and prescribes them for nations that are likewise demographically segmented. The four main principles are:

(1) The Grand Coalition: Governments are to be made up of representatives from each of a nation's major religious, linguistic, class, ethnic, or other demographic groupings. Their representatives are to share in executive power. 
(2) Proportionality: Each demographic group is required to have proportional representation in the government and in major political posts. Each demographic group is to be a "proportional beneficiary of public resources and expenditures" (McGarry and O'Leary 2006a, p. 44).

(3) Autonomy: Each demographic group is to have a guaranteed right to autonomy and self-governance.

(4) Mutual Veto-Rights: Representatives of each demographic group are to be granted the right to veto political actions that are deemed contrary to their group interests.

In order for these principles to succeed, the interests of each demographic group should be adequately and equally reflected in a grand coalition. If one of the groups which a consociational government attempts to represent feels marginalized by the state, the legitimacy of the consociational government system may become undermined (Farha 2012). Lijphart (1977) further argues that these principles are most likely to succeed when a strong case can be made that national unity is in the best interests of all groups in conflict. For example, groups at war may find cooperation under nationalistic terms to be beneficial when a mutual threat, external to their nation, is perceived.

\subsection{Empirical Support for Consociational Representation}

Consociational theorists credit consociationalism for successful peace efforts in Northern Ireland. Specifically, the British government's adoption of consociational policies that led to the Irish Republican Army's 1994 ceasefire agreement has been cited. Consociationalists also frequently cite Northern Ireland's 1998 Good Friday Agreement as an instance where adversarial political parties were able to agree on consociational principles, which have been largely beneficial for Northern Ireland. McGarry and O'Leary (2006b) elaborate by arguing that the consociational Good Friday Agreement is responsible for a dramatic decrease in violence in Northern Ireland.

Consociationalism has been credited for introducing more civil liberties to India's minority groups (Farha 2012; Lijphart 1996). Lijphart credits consociationalism with bringing fair representation to all of India's myriad of religious, linguistic, caste, and regional groups. Consociationalists argue that between 1947 and 1966 India was adhering closer to consociational principles than at any other point in Indian history and that this period was accompanied by the lowest rates of intergroup violence in the nation's history (Farha 2012; Lijphart 1996; Wilkinson 2000).

\subsection{Criticisms of Consociationalism}

Consociationalism is criticized for essentializing group identity to the political needs of individuals, to political disputes, and to government policy (Dixon 2011; Farha 2012; Haddad 2002; Hamzeh 2001). Political decisions and group gains and losses then become inextricably tied, which increases the degree to which religious identification is politically consequential ((Blumer 1958; Bobo and Hutchings 1996; Brown 2010; Sidanius and Pratto 2001) in (Huddy 2013)). As group identities become intrinsic to political decision making, socioeconomic and other prudential interests are rivaled by group identity (Nagle 2017). The individual then makes political decisions with the power associated with group membership in mind, while class interests are made subservient to group membership. With the government treating individuals by their identity first, and the individual being forced to choose their group identity as their foremost political concern, the likelihood that socioeconomic and other prudential needs are addressed significantly decreases.

Critics argue that consociational systems of government are unlikely to fairly represent all people, as representation is consolidated among specific group elites. Consociational victory is declared when political elites are publicly reconciled, while grassroots concerns are ignored. Consociational theorists assume that placing members of an ethnic group into political offices ensures that all members of an ethnic group are properly and equally represented. Consociational political structures also encourage segregation, limiting the opportunities for conflict resolution through intergroup contact (Dixon 2011). Critics note that this presupposes a one-dimensional view of ethnicity, which ignores the various 
social spaces occupied by individuals. While consociationalists see the distribution of resources among various ethnic or religious groups as promoting equality, critics argue that this ignores the strong potential for unequal distribution within groups (Wilkinson 2000).

Wilkinson (2000) cited India as a case refuting the effectiveness of consociational forms of governments for managing diverse societies. From 1919 until 1947, India experienced high levels of group conflict while adhering closely to consociational political principles. Wilkinson then argues that Lijphart (1996) was incorrect in labelling India's more peaceful period in the years 1947-1964 as consociational. In further contrast to Lijphart, Wilkinson argues that India became consociational again in 1965, and attributes an increase in religious, ethnic, and caste-based conflict to India becoming consociational again.

\subsection{Consociationalism in Lebanon}

Cammett and Issar (2010) describe Lebanon as a quasi, pseudo, or incomplete democracy. The degree to which power struggles are determined by democratic practices is limited. Rather, political parties and other sectarian leaders engage in activities outside of official channels in order to gain power. This includes encouraging protests, riots, and even "militia warfare" (Cammett and Issar 2010, p. 383). Frequent changes in Lebanon's electoral policies also may cheapen the value of electoral considerations, as political actors believe that electoral rules are easily subject to change.

According to the Taif Agreement, parliamentary seats are ascribed according to religious confession. However, Lebanon's political structure is also set up so that when a religious sect has a majority in a constituency, they are able to determine "the election of candidates supposedly representing another sect without them necessarily having the backing of a majority of their own sect" (Worrall et al. 2015, p. 92). This forces sects that are thinly and widely distributed to be represented by candidates who they did not vote for, even members of "rival factions" (Worrall et al. 2015, p. 92). This disproportionately affects Lebanon's Christian populations and benefits Hezbollah (Cammett and Issar 2010; Worrall et al. 2015). Lebanon's endorsement of consociationalism communicates the message to its citizens that their religious confession is the most important factor to consider when considering political representation and positions.

Farha (2012) argues that while consociationalism has helped to maintain diversity in Lebanon's government, this has come at the expense of the "usual standards of democracy and individual (as opposed to communal) rights" (Farha 2012, p. 376). As with other consociational governments, Lebanon's confessional consociational system often ignores class, religious, ideological, and other non-demographic identity based differences. With group identity trumping prudential political interests, the Lebanese government has addressed urbanization along prescribed confessional and "often primordial" lines (Harik 1996; Salamey and Tabar 2008, p. 244). During the post-war period, class-based and other interests have emerged, shaping and changing individual identities. Rather than acknowledging the class, regional, and other nationally inclusive identities that have arisen, Lebanon has drawn political borders, set up a government structure, and organized daily life in such a manner that places ultimate value on a person's confessional identity. Because these polices treat religious confessions as primary, and the government only recognizes eighteen religious confessions, these policies treat those with other or no religious confession as if they do not exist (Salamey and Tabar 2008).

\section{Hypotheses}

\subsection{State of Democracy}

While Lebanon's consociational arrangements were designed to fairly represent all of Lebanon's major confessional groups, critics argue that consociational arrangements have essentialized confessional identities to political matters in Lebanon. Rather than considering the economy, education, and other prudential needs, individuals frame political success in terms of their confessional group's relative power. Since the Taif Agreement was signed, Christians have felt collectively hurt by their 
relative political losses, while the Druze remain insecure in their minority status (Harris 2012). Additionally, a significant amount of political power has been transferred from Christians to Muslims, and Muslims have made significant relative political gains. Shia Muslims have been able to benefit from political and extra-political representation from Hezbollah. Frequent boycotts of elections, most notably by Christians, suggest flaws in Lebanon's democratic arrangement. Furthermore, if the critics of consociationalism are correct, all political losses are subject to interpretation as political losses.

H1: Evaluations of the state of democracy in Lebanon will be unequally distributed along confessional lines.

\subsection{Trust in Government Institutions}

Trust in government institutions is critical to social and political stability and is reflective on the legitimacy of a democracy (Kukovič 2013; Nikolayenko 2014). Low trust in government institutions is indicative of perceived discrimination (Liebkind and Jasinskaja-Lahti 2000). Perceptions of unfair treatment are likely to lead to decreased levels of political trust (Lee 1994). When political losses are perceived as group-identity losses, the implication is that one's ethnic or religious group is losing in a political system, indicating discrimination.

H2: Trust in government institutions will be unequally distributed along confessional lines.

\subsection{Perceptions of Freedoms}

Freedom is a basic and highly-desired value associated with liberal-democracies. Citizens should expect to be free to live their lives free from the coercion of others. Political freedoms are also to be expected, where individuals are freely able to participate in political and social activities in order to produce societal and governmental change (Berlin 2002; Heater 1999; Mulgan 1984; Naito 2007; Rawls 2001). Drawing on the historical record showing religious disparities in the benefits afforded by Lebanon's consociational governmental structure and the willingness of groups to participate in elections, I hypothesize that:

H3: Perceptions of freedom will be unequally distributed along religious lines.

\section{Methods}

\subsection{Data}

This research project utilizes the third wave of the Arab Barometer's survey of Lebanon. The Arab Barometer was established by scholars at multiple universities and research centers throughout the United States, Middle East, and North Africa. The project has been expanded through a partnership with the Arab Reform initiative. A national probability sample design is used to select nationally representative estimates of respondents in multiple Arab majority nations. Stratification techniques ensured representation from the seven governorates of Lebanon. The survey is stratified by socioeconomic status. Unlike many other well-known surveys of Lebanon, the Arab Barometer is stratified by religious confessions, separating Sunni and Shia Muslims. The sample is divided according Lebanon's 571 officially populated districts. Statistical blocks of 100-150 households served as primary sampling units. Households were randomly selected to recruit interview subjects to take part in face-to-face Arabic language surveys, yielding a total sample of 1060 respondents. (Arab 2014, 2016).

\subsection{Dependent Variables}

For the first set of analyses, an indicator of perceptions of democracy functions as the dependent variable. "Extent of democracy" asks respondents how democratic ( 0 , no democracy whatsoever, to 10 , democratic to the greatest possible extent) the respondent believes their country to be.

Next, four indicators of trust in government institutions were used as dependent variables. "Trust Government" asks respondents to what extent they trust their nation's government or cabinet. "Trust Parliament" asks respondents to what extent they trust Lebanon's Council of Representatives (the 
Parliament). "Trust Police" asks respondents to what extent they trust Lebanon's Internal Security Force (the police). "Trust Army" asks respondents to what extent they trust the Lebanese Army. For each of these variables, "I absolutely do not trust it" is treated as 0 while "I trust it to a limited extent," "I trust it to a medium extent" and "I trust it to a great extent" are treated as 1.

Finally, seven indicators of perceptions of freedoms functioned as dependent variables. "Freedom to Express Opinions" asks respondents to what extent the freedom to express opinions is guaranteed in their country. "Freedom of the Press" asks respondents to what extent freedom of the press is guaranteed in their country. "Freedom to Join Political Parties" asks respondents to what extent freedom to join political parties is guaranteed in their country. "Freedom to Protest" asks respondents to what extent freedom to participate in peaceful protests and demonstrations is guaranteed in their country. "Freedom to Join Civil Organizations" asks respondents to what extent freedom to join civil associations and organizations is guaranteed in their country. "Freedom to Sue the Government" asks respondents to what extent the freedom to sue the government and its agencies is guaranteed in their country. Finally, "Freedom to Vote" asks respondents to what extent the freedom to vote in parliamentary, municipal, and provincial elections is guaranteed in their country. For each of these variables, "not guaranteed" is treated as 0 , while "guaranteed to a limited extent," "guaranteed to a medium extent," and "guaranteed to a great extent" are treated as 1.

\subsection{Independent Variables}

Four religious categories were utilized. Respondents identified as (a) Maronite Catholic, (b) Sunni Muslim, (c) Shia Muslim (reference category), or (d) Druze. Shia Muslims are hypothesized to give the most positive evaluations of their government when compared to all of the confessional groups. Preliminary analyses revealed that Shia Muslims offer the most generous views of the government in nearly every measure. This made them a suitable choice for a reference category in regression models.

\subsection{Control Variables}

Key sociodemographic variables are controlled for. Rural living is coded as a dummy variable. Age is measured in years and captures respondents from the ages of 18 to 85 . Gender is reflected in the female dichotomous variable. Education is an ordinal variable where $1=$ illiterate/no formal education, 2 = elementary school education, 3 = preparatory/basic education, 4 = secondary school education, $5=$ mid-level diploma / professional or technical education, $6=$ bachelor's degree, and $7=$ master's degree. Employed is a dichotomous variable measuring employment status. Income includes the respondents' self-reported monthly household income. A log transformation was used on this variable to correct a skewed distribution. Initially, political party affiliation and regional governorates were controlled for. However, the models containing these variables revealed high levels of multicollinearity. This was anticipated, as consociationalism forces political affiliations to be drawn along religious lines. Thus, political party affiliation and religious identity are strongly correlated. Additionally, regional concentration of religious groups is also common in Lebanon (Harris 2012). Due to the problem of multi-collinearity, political party affiliation and regional governorate variables were dropped from the analysis.

\subsection{Analytic Procedure}

Table 2 presents descriptive statistics for all of the variables used in this study. Table 3 presents the mean of each of the socioeconomic variables by each religious group. 
Table 2. Descriptive Statistics.

\begin{tabular}{ccccc}
\hline Variables & Mean & SD & Min & Max \\
\hline Extent of Democracy & 4.22 & 2.70 & 0 & 10 \\
Trust Government & 0.321 & 0.47 & 0 & 1 \\
Trust Parliament & 0.42 & 0.49 & 0 & 1 \\
Trust Police & 0.68 & 0.47 & 0 & 1 \\
Trust Army & 0.88 & 0.32 & 0 & 1 \\
Freedom to Express Opinions & 0.78 & 0.46 & 0 & 1 \\
Freedom of the Press & 0.82 & 0.39 & 0 & 1 \\
Freedom to Join Political Parties & 0.89 & 0.31 & 0 & 1 \\
Freedom to Protest & 0.86 & 0.34 & 0 & 1 \\
Freedom to Join Civil Organizations & 0.92 & 0.28 & 0 & 1 \\
Freedom to Sue the Government & 0.36 & 0.48 & 0 & 1 \\
Freedom to Vote & 0.88 & 0.33 & 0 & 1 \\
Maronite & 0.30 & 0.46 & 0 & 1 \\
Sunni & 0.31 & 0.46 & 0 & 1 \\
Shia & 0.29 & 0.46 & 0 & 1 \\
Druze & 0.10 & 0.293 & 0 & 1 \\
Rural & 0.13 & 0.34 & 0 & 1 \\
Age & 40.15 & 15.01 & 18 & 85 \\
Female & 0.50 & 0.50 & 0 & 1 \\
Education & 3.85 & 1.70 & 1 & 7 \\
Employed & 0.66 & 0.47 & 0 & 1 \\
Income (logged) & 7.27 & 0.65 & 5.01 & 9.95 \\
\hline
\end{tabular}

Table 3. Mean Socioeconomic Descriptive Statistics by Religion.

\begin{tabular}{ccccc}
\hline Covariates & Maronite & Sunni & Shia & Druze \\
\hline Rural & 0.03 & 0.09 & 0.29 & 0.10 \\
Age & 46.48 & 38.33 & 36.28 & 37.74 \\
Female & 0.51 & 0.50 & 0.50 & 0.50 \\
Education & 3.60 & 3.92 & 4.10 & 3.65 \\
Employed & 0.66 & 0.64 & 0.65 & 0.73 \\
Income (logged) & 7.38 & 7.11 & 7.31 & 7.36 \\
\hline
\end{tabular}

Each subheading in the results sections of this paper begins by introducing a mean comparison of each religious group's responses to the questions being used as dependent variables. I use ordinary least squares modeling as a multivariate analytic strategy to test the relationships between religious identity and perceptions of democracy in Lebanon. I then utilize binary logistic regression modeling to test the relationships between religious identification and trust in government institutions. I end the study with binary logistic regression models that test the relationships between religious identity and perceptions of freedom in Lebanon ${ }^{1}$.

\section{Results}

\subsection{Descriptive Statistics}

Maronite, Sunni, and Shia respondents were almost evenly distributed among the sample and these religious groups compose just over $75 \%$ of the sample. Druze respondents were a clear minority, amounting to $8.33 \%$. A number of smaller Christian denominations made up the rest of the sample. Because their sample sizes were too small to detect statistical significance, these denominations were removed from the sample. In the final sample, Maronite, Sunni, and Shia respondents were almost evenly distributed, with about $90 \%$ of the sample adhering to one of these denominations. The remaining $9.53 \%$ of cases were Druze. The average respondent is about 40 year's old, lives in an urban setting, is female, has at least a preparatory/basic education, and is employed.

1 Initially ordered logistic regression models were run. Due to a violation of the proportional odds assumption, binary logistic models were estimated instead. 
Shia Muslims mostly lived in urban settings but were the most likely to live in rural settings, followed by Druze, Sunni Muslims, and Maronite Catholics respectively. The average age of respondents were similar with the exception of Maronite Catholics, who have the highest average age. Men and women were essentially equally distributed in the sample and among each of the religious groups. Income was slightly lower among Sunni Muslims, and Sunni Muslims were also slightly less likely than other groups to be employed.

\subsection{Extent of Democracy}

Table 4 presents mean comparisons for evaluations of the state of democracy in Lebanon across religious contexts. The findings here provide mixed preliminary support for H1. Only Shia Muslims rated the Lebanese government as more democratic than undemocratic. The mean democratic score given to Lebanon by Shia Muslims (5.21) is significantly higher than the scores given by Sunni Muslims, Maronite Catholics, and Druze. The mean evaluations given by Sunni Muslims, Maronite Catholics, and Druze do not significantly differ from each other.

Table 4. Religious Group Mean Evaluations of the State of Democracy in Lebanon.

\begin{tabular}{cc}
\hline Religious Groups & Extent of Democracy \\
\hline Maronite & $3.62^{\mathrm{a}}$ \\
Sunni & $3.93^{\mathrm{a}}$ \\
Shia & $5.21^{\mathrm{b}, \mathrm{c}, \mathrm{d}}$ \\
Druze & $4.09^{\mathrm{a}}$ \\
\hline
\end{tabular}

a Different from Shiites at 0.05 level or better. ${ }^{b}$ Different from Sunnis at 0.05 level or better. ${ }^{c}$ Different from Maronite Catholics at 0.05 level or better. ${ }^{\mathrm{d}}$ Different from Druze at 0.05 level or better.

As seen in Table 5, the OLS model supports $\mathrm{H} 1$ and the initial findings in the means comparisons. Controlling for all else, Shia Muslim respondents evaluate Lebanon as being significantly more democratic when compared to Maronite Catholics $(b=-1.52, p<0.001)$, Sunni Muslims $(b=-1.32$, $p<0.001)$ and Druze respondents $(b=-0.94, p<0.001)$. Maronites have the lowest scores in comparison, but Sunnis have lower scores than Druze. Females evaluated Lebanon as less democratic than did males, and the unemployed evaluated Lebanon as a less democratic nation when compared to employed respondents.

Table 5. Results from OLS Regression Model Predicting Evaluations of the State of Democracy.

\begin{tabular}{cc}
\hline Independent Variables & Extent of Democracy \\
\hline Intercept $^{\text {Maronite }}$ & $6.00^{* * *}$ \\
Sunni $^{\text {a }}$ & $-1.52^{* * *}$ \\
Druze $^{\text {a }}$ & $-1.32^{* * *}$ \\
Rural & $-0.94^{* *}$ \\
Age & 0.05 \\
Female & -0.002 \\
Education & $-0.50^{*}$ \\
Employed & 0.09 \\
Income (logged) & $-0.40^{*}$ \\
N & -0.07 \\
R-Square & 954 \\
${ }^{*} p<0.05,{ }^{* *} p<0.01^{* * *} p<0.001$. Notes: ${ }^{\text {a }}$ Reference group is Shia Muslim.
\end{tabular}

\subsection{Trust in Government Institutions}

Table 6 provides comparisons of means on trust in institutions among the four religious groups that this study focuses on. Sunni and Shia Muslims are both significantly more trusting of the government than are Maronite Catholic and Druze respondents, while not significantly differing from 
each other. Shia Muslims are significantly more trusting of Lebanon's democratically elected parliament when compared to members of all the other religious groups. Sunni Muslims are significantly more trusting of the parliament than Maronite and Druze respondents. Shia Muslims were more trusting of the police than Sunni Muslims and Maronite Catholics. No significant differences were observed between Druze respondents and the other religious groups in their trust of the police. Druze, Shia, and Maronite respondents do not significantly vary from each other in their trust in the Lebanese Army, but they are all significantly more trusting of the Lebanese army than are Sunni respondents.

Table 6. Religious Group Mean Trust in Government Institutions.

\begin{tabular}{ccccc}
\hline Religious Groups & Trust Government & Trust Parliament & Trust Police & Trust Army \\
\hline Maronite & $0.20^{\mathrm{a}, \mathrm{b}}$ & $0.22^{\mathrm{a}, \mathrm{b}}$ & $0.61^{\mathrm{a}}$ & $0.93^{\mathrm{b}}$ \\
Sunni & $0.42^{\mathrm{c}, \mathrm{d}}$ & $0.44^{\mathrm{a}, \mathrm{c}, \mathrm{d}}$ & $0.66^{\mathrm{a}}$ & $0.74^{\mathrm{a}, \mathrm{c}, \mathrm{d}}$ \\
Shia & $0.38^{\mathrm{c}, \mathrm{d}}$ & $0.65^{\mathrm{b}, \mathrm{c}, \mathrm{d}}$ & $0.76^{\mathrm{b}, \mathrm{c}}$ & $0.95^{\mathrm{b}}$ \\
Druze & $0.22^{\mathrm{a}, \mathrm{b}}$ & $0.24^{\mathrm{a}, \mathrm{b}}$ & 0.70 & $0.96^{\mathrm{b}}$ \\
\hline
\end{tabular}

a Different from Shiites at 0.05 level or better. ${ }^{b}$ Different from Sunnis at 0.05 level or better. ${ }^{c}$ Different from Maronites at 0.05 level or better. ${ }^{\mathrm{d}}$ Different from Druze at 0.05 level or better.

Table 7 presents the results from four binary logistic regression models estimating trust in government institutions among religious groups, net control variables. These findings provide mixed support for $\mathrm{H} 2$.

When it comes to having a general trust in the government and trust in the police, Shia Muslims only have significantly higher odds of trust when compared to Maronite Catholics. When it comes to trust in the army, Shia Muslims only have higher odds of trust when compared to Sunni Muslims. However, Shia Muslims are significantly more likely to be trusting of Lebanon's parliament when compared to members of all three of the other religious confessions. This is unsurprising, considering that Lebanon's consociational arrangements require that the leader of the nation's parliament be a Shia Muslim.

Table 7. Estimated Odds Ratios for Trust in Institutions.

\begin{tabular}{|c|c|c|c|c|}
\hline Independent Variables & Trust Government & Trust Parliament & Trust Police & Trust Army \\
\hline Maronite $^{a}$ & $\begin{array}{c}0.45^{* * *} \\
(0.21)\end{array}$ & $\begin{array}{c}0.20^{* * *} \\
(0.20)\end{array}$ & $\begin{array}{l}0.55^{* *} \\
(0.20)\end{array}$ & $\begin{array}{c}0.57 \\
(0.38)\end{array}$ \\
\hline Sunni ${ }^{a}$ & $\begin{array}{c}1.32 \\
(0.18)\end{array}$ & $\begin{array}{c}0.48^{* * *} \\
(0.18)\end{array}$ & $\begin{array}{c}0.71 \\
(0.19)\end{array}$ & $\begin{array}{c}0.14^{* * *} \\
(0.31)\end{array}$ \\
\hline Druze $^{a}$ & $\begin{array}{c}0.62 \\
(0.29)\end{array}$ & $\begin{array}{c}0.22 * * * \\
(0.29)\end{array}$ & $\begin{array}{c}0.90 \\
(0.29)\end{array}$ & $\begin{array}{c}1.92 \\
(0.77)\end{array}$ \\
\hline Rural & $\begin{array}{c}1.24 \\
(0.21)\end{array}$ & $\begin{array}{c}2.24^{* * *} \\
(0.22)\end{array}$ & $\begin{array}{l}2.04^{* *} \\
(0.26)\end{array}$ & $\begin{array}{c}0.93 \\
(0.34)\end{array}$ \\
\hline Age & $\begin{array}{c}0.99 \\
(0.005)\end{array}$ & $\begin{array}{c}0.99 \\
(0.005)\end{array}$ & $\begin{array}{c}1.01 \\
(0.005)\end{array}$ & $\begin{array}{c}1.01 \\
(0.008)\end{array}$ \\
\hline Female & $\begin{array}{c}0.84 \\
(0.15)\end{array}$ & $\begin{array}{c}0.88 \\
(0.15)\end{array}$ & $\begin{array}{c}1.27 \\
(0.15)\end{array}$ & $\begin{array}{c}1.55 \\
(0.23)\end{array}$ \\
\hline Education & $\begin{array}{c}1.06 \\
(0.05)\end{array}$ & $\begin{array}{c}1.06 \\
(0.05)\end{array}$ & $\begin{array}{c}1.03 \\
(0.05)\end{array}$ & $\begin{array}{c}1.02 \\
(0.07)\end{array}$ \\
\hline Employed & $\begin{array}{l}0.65^{* *} \\
(0.16)\end{array}$ & $\begin{array}{c}0.86 \\
(0.16)\end{array}$ & $\begin{array}{c}0.90 \\
(0.16)\end{array}$ & $\begin{array}{c}1.31 \\
(0.24)\end{array}$ \\
\hline Income (logged) & $\begin{array}{c}0.90 \\
(0.12)\end{array}$ & $\begin{array}{l}0.77^{*} \\
(0.12)\end{array}$ & $\begin{array}{c}0.96 \\
(0.12)\end{array}$ & $\begin{array}{c}0.93 \\
(0.18)\end{array}$ \\
\hline $\mathrm{N}$ & 955 & 951 & 954 & 954 \\
\hline-2 Log Likelihood & 1202.39 & 1295.55 & 1181.66 & 694.17 \\
\hline
\end{tabular}


Control variables were significant to a minimal extent, which is consistent with the criticism that consociationalism reinforces religious identity based differences over economic, class, and other political needs. Employed respondents are less trusting of the government. Income is negatively associated with trust in the parliament. Rural-based respondents had greater odds of trusting the parliament and the police when compared to urban-dwelling respondents.

\subsection{Perceptions of Freedom}

Results presented in Table 8 reveal that evaluations of the freedoms that are guaranteed in Lebanon were generally high, with the exception of the freedom to sue the government. In each case, Shia respondents reported the highest levels of perceived freedoms. Shia respondents were more likely to believe that Lebanon guarantees the freedom to express opinions than were members of all the other religious groups. Sunni respondents were more likely to believe that Lebanon guarantees the freedom to express opinions than were Druze and Maronite respondents. Shia respondents were significantly more likely than Sunni and Maronite respondents to report that their government guarantees press freedoms, while Sunni respondents were more likely to report that their government guarantees press freedom than Maronite respondents. Shia respondents were significantly more likely to believe that Lebanon guarantees the freedom to join political parties than were Sunni, Druze, and Maronite respondents, while none of the other religious groups differed among themselves. Shia respondents were also significantly more likely that Sunni, Druze, and Maronite respondents to report that Lebanon guarantees the freedom to participate in peaceful protests. Sunni respondents were more likely to report that Lebanon guarantees the freedom to protest when compared to Maronite respondents. Shia respondents were more likely than Maronite respondents to say that Lebanon guarantees the freedom to join civil associations and organizations. Shia respondents were more likely to report that Lebanon guarantees the freedom to sue the government when compared to respondents from all other religious groups. Shia Muslims were also the only religious group to believe on average that the government of Lebanon provides the freedom to sue the government. Sunni respondents were more likely to believe that Lebanon guarantees the freedom to sue the government when compared to Maronite respondents. Sunni and Shia respondents were both significantly more likely to report that Lebanon guarantees the freedom to vote when compared to Maronite respondents.

Table 8. Religious Group Mean Perceptions of Freedom.

\begin{tabular}{|c|c|c|c|c|c|c|c|}
\hline $\begin{array}{l}\text { Religious } \\
\text { Groups }\end{array}$ & $\begin{array}{c}\text { Freedom to } \\
\text { Express Opinions }\end{array}$ & $\begin{array}{l}\text { Freedom of the } \\
\text { Press }\end{array}$ & $\begin{array}{c}\text { Join Political } \\
\text { Parties }\end{array}$ & $\begin{array}{l}\text { Freedom } \\
\text { to Protest }\end{array}$ & $\begin{array}{l}\text { Freedom to Join } \\
\text { Civil Associations }\end{array}$ & $\begin{array}{l}\text { Freedom to Sue the } \\
\text { Government }\end{array}$ & $\begin{array}{c}\text { Freedom } \\
\text { to Vote }\end{array}$ \\
\hline Sunni & $0.83^{\mathrm{a}, \mathrm{c}, \mathrm{d}}$ & $0.83^{a, c}$ & $0.89^{a}$ & $0.86^{a, c}$ & 0.91 & $0.38^{a, c}$ & $0.89^{c}$ \\
\hline Druze & $0.67^{\mathrm{a}, \mathrm{b}}$ & 0.80 & $0.86^{\mathrm{a}}$ & $0.82^{\mathrm{a}}$ & 0.92 & $0.26^{\mathrm{a}}$ & 0.90 \\
\hline
\end{tabular}

${ }^{a}$ Different from Shiites at 0.05 level or better. ${ }^{b}$ Different from Sunnis at 0.05 level or better. ${ }^{c}$ Different from Maronites at 0.05 level or better. ${ }^{d}$ Different from Druze at 0.05 level or better.

Table 9 presents data offering mixed support for H3. Religious disparities in favor of Shia Muslims were observed with each freedom except for the freedom to vote. Shia Muslims had higher odds of perceiving Lebanon as guaranteeing the freedom to express opinions, the freedom to join political parties, the freedom to participate in peaceful protests and demonstrations, and the freedom to sue the government when compared to Sunni, Maronite, and Druze respondents. Shia Muslims had higher odds than Maronite and Sunni respondents of believing that the freedom of the press and the freedom to join civil associations and organizations were guaranteed in Lebanon. 
Table 9. Estimated Odds Ratios for Perceptions of Freedom in Lebanon.

\begin{tabular}{|c|c|c|c|c|c|c|c|}
\hline $\begin{array}{l}\text { Independent } \\
\text { Variables }\end{array}$ & $\begin{array}{c}\text { Freedom to } \\
\text { Express Opinions }\end{array}$ & $\begin{array}{l}\text { Freedom of } \\
\text { the Press }\end{array}$ & $\begin{array}{l}\text { Freedom to Join } \\
\text { Political Parties }\end{array}$ & Freedom to Protest & $\begin{array}{l}\text { Freedom to Join } \\
\text { Civil Associations }\end{array}$ & $\begin{array}{l}\text { Freedom to Sue the } \\
\text { Government }\end{array}$ & $\begin{array}{l}\text { Freedom } \\
\text { to Vote }\end{array}$ \\
\hline Maronite $^{\mathrm{a}}$ & $\begin{array}{l}0.09 * * * \\
(0.32)\end{array}$ & $\begin{array}{l}0.30^{* * *} \\
(0.26)\end{array}$ & $\begin{array}{c}0.17^{* * *} \\
(0.41)\end{array}$ & $\begin{array}{l}0.18^{* * *} \\
(0.34)\end{array}$ & $\begin{array}{c}0.26^{* * *} \\
(0.39)\end{array}$ & $\begin{array}{l}0.26^{* * *} \\
(0.20)\end{array}$ & $\begin{array}{c}0.65 \\
(0.27)\end{array}$ \\
\hline Sunni ${ }^{\text {a }}$ & $\begin{array}{l}0.21^{* * *} \\
(0.33)\end{array}$ & $\begin{array}{l}0.57^{*} \\
(0.26)\end{array}$ & $\begin{array}{l}0.23^{* * *} \\
(0.41)\end{array}$ & $\begin{array}{l}0.30^{* * *} \\
(0.34)\end{array}$ & $\begin{array}{l}0.36^{* *} \\
(0.38)\end{array}$ & $\begin{array}{l}0.60^{* *} \\
(0.17)\end{array}$ & $\begin{array}{c}1.03 \\
(0.28)\end{array}$ \\
\hline Druze $^{a}$ & $\begin{array}{l}0.12 * * * \\
(0.38)\end{array}$ & $\begin{array}{c}0.57 \\
(0.37)\end{array}$ & $\begin{array}{l}0.22 * * \\
(0.51)\end{array}$ & $\begin{array}{c}0.23 * * * \\
(0.42)\end{array}$ & $\begin{array}{c}0.58 \\
(0.59)\end{array}$ & $\begin{array}{l}0.41^{* *} \\
(0.28)\end{array}$ & $\begin{array}{c}1.81 \\
(0.51)\end{array}$ \\
\hline Rural & $\begin{array}{c}0.98 \\
(0.33)\end{array}$ & $\begin{array}{c}2.03 \\
(0.37)\end{array}$ & $\begin{array}{c}1.95 \\
(0.50)\end{array}$ & $\begin{array}{l}2.60^{*} \\
(0.48)\end{array}$ & $\begin{array}{l}1.76 \\
(0.50)\end{array}$ & $\begin{array}{c}1.28 \\
(0.21)\end{array}$ & $\begin{array}{l}3.33^{*} \\
(0.48)\end{array}$ \\
\hline Age & $\begin{array}{l}0.98^{* *} \\
(0.006)\end{array}$ & $\begin{array}{c}1.00 \\
(0.006)\end{array}$ & $\begin{array}{c}0.99 \\
(0.008)\end{array}$ & $\begin{array}{c}1.00 \\
(0.006)\end{array}$ & $\begin{array}{c}0.99 \\
(0.008)\end{array}$ & $\begin{array}{c}1.00 \\
(0.005)\end{array}$ & $\begin{array}{c}1.00 \\
(0.007)\end{array}$ \\
\hline Female & $\begin{array}{c}0.82 \\
(0.19)\end{array}$ & $\begin{array}{c}1.14 \\
(0.19)\end{array}$ & $\begin{array}{c}0.87 \\
(0.23)\end{array}$ & $\begin{array}{c}0.94 \\
(0.21)\end{array}$ & $\begin{array}{c}1.11 \\
(0.26)\end{array}$ & $\begin{array}{c}1.01 \\
(0.15)\end{array}$ & $\begin{array}{c}0.93 \\
(0.22)\end{array}$ \\
\hline Education & $\begin{array}{c}1.04 \\
(0.06)\end{array}$ & $\begin{array}{c}1.02 \\
(0.06)\end{array}$ & $\begin{array}{c}0.96 \\
(0.07)\end{array}$ & $\begin{array}{c}0.98 \\
(0.06)\end{array}$ & $\begin{array}{l}0.86^{*} \\
(0.08)\end{array}$ & $\begin{array}{l}1.00 \\
(0.04)\end{array}$ & $\begin{array}{c}0.91 \\
(0.07)\end{array}$ \\
\hline Employed & $\begin{array}{c}1.02 \\
(0.20)\end{array}$ & $\begin{array}{c}1.11 \\
(0.20)\end{array}$ & $\begin{array}{c}0.89 \\
(0.25)\end{array}$ & $\begin{array}{c}0.76 \\
(0.23)\end{array}$ & $\begin{array}{c}1.09 \\
(0.27)\end{array}$ & $\begin{array}{l}0.68^{*} \\
(0.16)\end{array}$ & $\begin{array}{c}0.93 \\
(0.23)\end{array}$ \\
\hline $\begin{array}{l}\text { Income } \\
\text { (logged) }\end{array}$ & $\begin{array}{c}0.81 \\
(0.13)\end{array}$ & $\begin{array}{c}1.12 \\
(0.14)\end{array}$ & $\begin{array}{c}1.05 \\
(0.17)\end{array}$ & $\begin{array}{c}0.94 \\
(0.15) \\
\end{array}$ & $\begin{array}{c}1.12 \\
(0.19)\end{array}$ & $\begin{array}{c}0.99 \\
(0.12)\end{array}$ & $\begin{array}{c}1.20 \\
(0.17)\end{array}$ \\
\hline $\mathrm{N}$ & 959 & 956 & 952 & 956 & 958 & 946 & 957 \\
\hline $\begin{array}{c}-2 \text { Log } \\
\text { Likelihood }\end{array}$ & 968.58 & 885.71 & 579.45 & 763.91 & 494.32 & 1239.05 & 686.85 \\
\hline
\end{tabular}

In these models, the effects of socioeconomic factors again were minimal. Age only had a slight and significant negative relationship with perceiving the right to express opinions as being guaranteed in Lebanon. Increased education was associated with having lower odds of perceiving Lebanon as guaranteeing the right to join civil associations and organizations. Being employed was associated with having lower odds of perceiving Lebanon as guaranteeing the right to sue the government and its agencies. Rural respondents had higher odds of perceiving the right to protest and vote as being guaranteed in Lebanon when compared to urban voters.

\section{Discussion}

Scholars who are critical of consociationalism have argued that consociational representation does not provide proper political accommodations and representation to the religious and ethnic groups that consociationalism intends to help. Rather, critics argue that consociationalism essentializes group identity to political disputes (Dixon 2011; Farha 2012; Haddad 2002; Hamzeh 2001). Historians of Lebanon have added on to this the fact that historical contingencies have worked primarily to the favor of Muslim groups and against Christians (El-Husseini 2012; Haddad 2002; Harris 2012). The Taif Agreement, which sought to distribute political power across warring religious factions, re-established a consociational government in Lebanon. Historical research suggest that Christians emerged out of post-war Lebanon united with a sense of defeat and the Druze with a decreased sense of security (El-Husseini 2012; Harris 2012). Lebanon's Muslim populations have benefitted from power shifts. However, there has not been one monolithic Muslim experience. Sunnis and Shias have often enjoyed different benefits. Additionally, political events have at times raised inter-sectarian tensions (Bahout 2016; Cammett and Issar 2010; El-Husseini 2012; Harik 1996; Harris 2012; Hamzeh 1994; Khashan and Mousawi 2007).

My findings are consistent with the arguments of critics of consociationalism and historians who observe religious disparities in Lebanon's current consociational arrangements. In ten out of twelve models investigating equal outcomes for the state of democracy, Maronite respondents consistently feel that the state of Lebanon is less democratic, less trustworthy, and less free when compared to Shia Muslims. Similar disparities were observed between Shia and Sunni Muslims in nine out of the twelve models. Similar findings were also found between Shia Muslims and Druze respondents. Fewer significant findings with Druze respondents may be due to the small sample size of the Druze. Means comparisons reveal additional layers of a stratified political experience. In no models were members of any religious group evaluate Lebanon as more democratic, more trustworthy, or freer 
than Shia Muslims. These findings lend support to critics of consociational theory, who argue that consociationalism essentializes group identity differences to politics and forces individuals to consider religious group interests instead of economic and other self-interests. What is particularly noteworthy are the nearly negligible socioeconomic effects on political views. While education, gender, and income are expected to appreciably affect political attitudes, these variables only appear as significant, often marginally so, in less than half of the models. On the other hand, religious group differences were observed in all but one of the twelve models. This is consistent with the argument that confessionalism leads Lebanese citizens to ignore their prudential interests in favor of religious group-based interests (Nagle 2017).

Acknowledgments of limitations and points of clarification regarding this study are warranted. This study does not, and due to the constraints of the data, cannot argue for a causal relationship between the establishment of a consociational democracy and political attitudes in Lebanon. Data on political attitudes in Lebanon before and after the implementation of consociational agreements are unfortunately not available. Furthermore, this study cannot directly place consociationalism in comparison with other political structures. What scholars can do and have done is investigate whether or not consociationalism succeeds on its own merits by creating strong democracies with equal and satisfactory conditions for the groups that consociational political engineers are attempting to accommodate. Taking this approach, my research finds that members of most religious groups do not believe that they are living in a very democratic state. I find alarming levels of political distrust, an important indicator of the strength of a democracy. In these areas and within views of freedoms guaranteed in Lebanon, I also find evidence of multiple significant religious disparities in the ways that members of religious major religious confessions experience the benefits of a consociational democratic government.

One direction future research may take in order to address the limitations of this study is to apply a comparative-historical treatment to Lebanon and consociationalism. In addition to consociationalism, several other power-sharing arrangements have been proposed and implemented to appease deeply divided nations. Rather than focusing on minority-group members representing themselves in politics, centripetalists argue for a political structure that incentivizes majority-group political representatives to accommodate the needs of minority-group members (McCulloch 2013). Political appeals made across ethnic, racial, or religious lines are argued to ensure the political support and inclusion of majority and minority-group members. Additionally, advocates of federacy call for "an autonomous political region in an otherwise unitary or union state" (O'Leary 2013, p.403) to be implemented in deeply divided places. Those represented by the federacy are entitled to self-government in terms of the law and the structuring of regional and local government. The federacy, and those it represents, would then benefit from a significant degree of sovereignty from the national government and those the national government primarily represents (Mcgarry 2007; O’Leary 2013; Rezvani 2007; Stepan 2013). Other scholars argue that courts may constrain the powers of majoritarian governments, defend the rights of minority groups members, and maintain democratic stability. These courts may not need to rely on any special form of government specifically designed for power-sharing (Issacharoff 2013). Comparative-historical research investigating multiple consociational governments as well as governments representing other power-sharing arrangement help scholars to further isolate and understand the effects of consociationalism when compared to other systems of governance.

Conflicts of Interest: The author declares no conflict of interest.

\section{References}

Arab, Barometer. 2014. Codebook Arab Democracy Barometer Wave III 2012-2014. Available online: http:/ / www.arabbarometer.org/sites/default/files/code_book/Arab\%20Barometer\%20Wave\% 20Three\%20Codebook.pdf (accessed on 22 February 2016). 
Arab, Barometer. 2016. Arab Democracy, in Partnership with the Arab Reform Initiative. Available online: http:/ / www.arabbarometer.org/introduction (accessed on 21 July 2016).

Bahout, Joseph. 2016. The Unraveling of Lebanon's Taif Agreement: Limits of Sect-Based Power Sharing. Available online: https: / / carnegieendowment.org/2016/05/16/unraveling-of-lebanon-s-taif-agreement-limits-ofsect-based-power-sharing-pub-63571 (accessed on 31 August 2017).

Baylouny, Anne Marie. 2014. Born Violent: Armed Political Parties and Non-State Governance in Lebanon's Civil War. Small Wars E Insurgencies 25: 329-53.

Berlin, Isaiah. 2002. Four Essays on Liberty. In Liberty. Edited by Hardy, Henry. Oxford: Oxford University Press, pp. 3-279.

Blumer, Herbert. 1958. Race Prejudice as a Sense of Group Position. The Pacific Sociological Review 1: 3-7. [CrossRef] Bobo, Lawrence, and Vincent L. Hutchings. 1996. Perceptions of Racial Group Competition: Extending Blumer's Theory of Group Position to a Multiracial Social Context. American Sociological Review 61: 951-72. [CrossRef]

Brown, Rupert. 2010. Prejudice: It's Social Psychology. Hoboken: Wiley-Blackwell.

Cammett, Melani, and Sukriti Issar. 2010. Bricks and Mortar Clientelism: Sectarianism and the Logics of Welfare Allocation in Lebanon. World Politics 62: 381-421. [CrossRef] [PubMed]

Dixon, Paul. 2011. Is Consociational Theory the Answer to Global Conflict? From the Netherlands to Northern Ireland and Iraq. Political Studies Review 9: 309-22. [CrossRef]

El-Husseini, Rola. 2012. Pax Syriana: Elite Politics in Postwar Lebanon, 1st ed. Syracuse: Syracuse University Press.

Farha, Mark. 2012. Global Gradations of Secularism: The Consociational, Communal and Coercive Paradigms. Comparative Sociology 11: 354-86. [CrossRef]

Finke, Roger. 2013. Presidential Address Origins and Consequences of Religious Freedoms: A Global Overview. Sociology of Religion 74: 297-313. [CrossRef] [PubMed]

Finke, Roger, and Rodney Stark. 2005. The Churching of America, 1776-2005: Winners and Losers in Our Religious Economy, rev. ed. New Brunswick: Rutgers University Press.

Gill, Anthony James. 1998. Rendering unto Caesar: The Catholic Church and the Statein Latin America. Chicago: University of Chicago Press.

Gill, Anthony James. 2008. The Political Origins of Religious Liberty. New York: Cambridge University Press.

Grim, Brian J. 2008. Religious Freedom: Good for What Ails Us? The Review of Faith E International Affairs 6: 3-7.

Grim, Brian J., and Roger Finke. 2007. Religious Persecution in Cross-National Context: Clashing Civilizations or Regulated Religious Economies? American Sociological Review 72: 633-58. [CrossRef]

Grim, Brian J., and Roger Finke. 2010. The Price of Freedom Denied: Religious Persecution and Conflict in the Twenty-First Century. New York: Cambridge University Press.

Haddad, Simon. 2002. Cultural Diversity and Sectarian Attitudes in Postwar Lebanon. Journal of Ethnic $\mathcal{E}$ Migration Studies 28: 291-306.

Hamzeh, A. Nizar. 1994. Clan Conflicts, Hezbollah \& the Lebanese State. The Journal of Social, Political, and Economic Studies 19: 433-46.

Hamzeh, Ahmed. 2001. Clientalism in Lebanon: Roots and Trends. Middle Eastern Studies 37: 167-78. [CrossRef]

Harik, Judith Palmer. 1996. Between Islam and The System: Sources and Implication of Popular Support for Lebanon's Hizballah. The Journal of Conflict Resolution 40: 41-67. [CrossRef]

Harris, William. 2012. Lebanon: A History, 600-2011. New York: OUP USA.

Heater, Derek. 1999. What Is Citizenship? Cambridge: Polity Press.

Huddy, Leonie. 2013. From Group Identity to Political Cohesion and Commitment. In The Oxford Handbook of Political Psychology, 2nd ed. Edited by Huddy, Leonie, David O. Sears and Jack S. Levy. Oxford: Oxford University Press, pp. 737-54.

Issacharoff, Samuel. 2013. Courts, Constitutions, and the Limits of Majoritarianism. In Power Sharing in Deeply Divided Places. Edited by McEvoy, Joanne and Brendan O'Leary. Philadelphia: University of Pennsylvania Press, pp. 214-27.

Khashan, Hilal, and Ibrahim Mousawi. 2007. Hizbullah's Jihad Concept. Journal of Religion E Society 9: 1-19.

Kreidie, Lina Haddad, and Kristen Renwick Monroe. 2002. Psychological Boundaries and Ethnic Conflict: How Identity Constrained Choice and Worked to Turn Ordinary People Into Perpetrators of Ethnic Violence During the Lebanese Civil War. International Journal of Politics, Culture E Society 16: 5-36.

Kukovič, Simona. 2013. Distrust in Political Institutions: Comparisons between New Democracies of Central and Eastern Europe. Journal of Comparative Politics 6: 20-30. 
Lee, Aie-Rie. 1994. Economics vs. Values in Political Trust in Korea. Studies in Comparative International Development 29: 25-40. [CrossRef]

Liebkind, Karmela, and Inga Jasinskaja-Lahti. 2000. The Influence of Experience of Discrimination on Psycholgoical Stress: A Comparison of Seven Immigrant Groups. Journal of Community \& Applied Social Psychology 10: 1-16.

Lijphart, Arend. 1977. Democracy in Plural Societies: A Comparative Exploration. New Haven: Yale University Press. Lijphart, Arend. 1996. The Puzzle of Indian Democracy: A Consociational Interpretation. The American Political Science Review 90: 258-68. [CrossRef]

MacKey, Sandra. 1991. Lebanon: Death of a Nation. New York: Doubleday.

McCulloch, Allison. 2013. Does Moderation Pay? Centripetalism in Deeply Divided Societies. Ethnopolitics 12 : 111-32. [CrossRef]

Mcgarry, John. 2007. Asymmetry in Federations, Federacies and Unitary States. Ethnopolitics 6: 105-16. [CrossRef]

McGarry, John, and Brendan O'Leary. 2006a. Consociational Theory, Northern Ireland's Conflict, and Its Agreement. Part 1: What Consociationalists Can Learn from Northern Ireland. Government and Opposition 41: 43-63. [CrossRef]

McGarry, John, and Brendan O'Leary. 2006b. Consociational Theory, Northern Ireland's Conflict, and Its Agreement. 2. What Critics of Consociation Can Learn from Northern Ireland. Government and Opposition 41: 249-77. [CrossRef]

Mulgan, Richard. 1984. Liberty in Ancient Greece. In Conceptions in Political Philosophy. Edited by Pelczynski, Zbigniew and John Gray. London: Athlone Press, pp. 7-26.

Nagle, John. 2017. Beyond Ethnic Entrenchment and Amelioration: An Analysis of Non-Sectarian Social Movements and Lebanon's Consociationalism. Ethnic and Racial Studies, 1-20. [CrossRef]

Naito, Jun. 2007. Perceived Freedom and Its Sociological Effects: An Inquiry into the Relationship between Liberalism and Inequality. International Journal of Japanese Sociology 16: 80-99. [CrossRef]

Nikolayenko, Olena. 2014. Trust in Government and Goal Pursuit in a Transition Society. Comparative Sociology 13: 618-38. [CrossRef]

O'Leary, Brendan. 2013. Power Sharing: An Advocate's Conclusion. In Power Sharing in Deeply Divided Places. Edited by McEvoy, Joanne and Brendan O'Leary. Philadelphia: University of Pennsylvania Press, pp. 386-422.

Pew Forum on Religion and Public Life-A Project of the Pew Research Center. 2014. Religious Hostilities Reach Six-Year High. Available online: www.pewforum.org/2014/01/14/religious-hostilities-reach-six-year-high/ (accessed on 1 December 2015).

Rawls, John. 2001. Justice as Fairness: A Restatment. Cambrdige: The Belknap Press of Harvard University Press. Rezvani, David A. 2007. Shaping the Federacy Research Agenda. Ethnopolitics 6: 129-31. [CrossRef]

Salamey, Imad. 2013. Government and Politics of Lebanon. Florence: Taylor and Francis, Available online: http: / / site.ebrary.com/lib/alltitles/docDetail.action?docID=10783091 (accessed on 21 February 2016).

Salamey, Imad, and Paul Tabar. 2008. Consociational Democracy and Urban Sustainability: Transforming the Confessional Divides in Beirut. Ethnopolitics 7: 239-63. [CrossRef]

Sidanius, Jim, and Felicia Pratto. 2001. Social Dominance: An Intergroup Theory of Social Hierarchy and Oppression, 1st ed. Cambridge: Cambridge University Press.

Stark, Rodney, and Finke Roger. 2000. Acts of Faith: Explaining the Human Side of Religion. Berkeley: University of California Press.

Stepan, Alfred. 2013. A Revised Theory of Federacy and a Case Study of Civil War Termination in Aceh, Indonesia. In Power Sharing in Deeply Divided Places. Edited by McEvoy, Joanne and Brendan O'Leary. Philadelphia: University of Pennsylvania Press, pp. 232-52.

Wilkinson, Steven Ian. 2000. India, Consociational Theory, and Ethnic Violence. Asian Survey 40: 767-91. [CrossRef] Worrall, James, Simon Mabon, and Gordon Clubb. 2015. Praeger Security International: Hezbollah: From Islamic Resistance to Government. Santa Barbara: ABC-CLIO.

(C) 2018 by the author. Licensee MDPI, Basel, Switzerland. This article is an open access article distributed under the terms and conditions of the Creative Commons Attribution (CC BY) license (http:/ / creativecommons.org/licenses/by/4.0/). 